\section{Strengthening cultural values for primate conservation on Mentawai Island, Indonesia}

The Mentawai Islands (Siberut, Sipora and North and South Pagai) are home to five endemic primate species: the Mentawai langur Presbytis potenziani, Pagai macaque Macaca pagensis, Siberut macaque Macaca siberu, Kloss's gibbon Hylobates klossii and the pigtailed langur Simias concolor. These primates are celebrated in local culture, reflected in dances and songs used in traditional ceremonies, and are believed to be an intermediary for communication with ancestors. But in Mentawai culture primate hunting is also important. Boys are introduced to hunting in the forest in their early years. As a result of the combination of habitat loss and hunting, primates in particular are severely threatened in the Mentawai Islands. Housing subsidies from the government have caused families to move out of the forest, distancing them from their cultural value systems that were formerly intertwined with nature. Because of these problems, the NGO SwaraOwa and Malinggai Uma Traditional Mentawai (a local community that constructs a traditional longhouse where they conduct ceremonial and tribal activities) in southern Siberut, are working to introduce primate conservation to the community, to rejuvenate Mentawai culture through teacher training.

The training aims to build the capacity of local teachers, encouraging the inclusion of primate conservation in school curricula by introducing a board game, a card game and primate watching in the field. The first training was carried out during 25-27 November 2020, at
Malinggai Uma, attended by 13 teachers from Siberut and Sipora islands. The event was also attended by Mentawaian elders and representatives of the Mentawai regional government. Participants were introduced to the board game Owa (gibbon; similar to Monopoly) created by teachers in Central Java to promote Javan gibbon conservation. During the discussion, teachers were supported to develop a card game (similar to Go Fish) based on Mentawai primate species. A field trip was conducted in Tololago forest, to introduce primate watching as an activity in which teachers and students can learn about primates in their natural habitat and about methods to observe and record primates.

One group of teachers observed Kloss's gibbon and the Siberut macaque. Another group observed Siberut flying squirrels Petinomys lugens, which are also endemic to the island. We hope that this training session will help teachers share their experience in the field and their new knowledge to encourage their students to care for their surrounding forest and protect the remaining primate species of the Mentawai Islands. We are currently seeking a grant to carry out additional training with teachers, and other conservation activities, in Mentawai.

EKA CAHYANINGRUM (৫ orcid.org/0000-0001-7850-9921) and ARIF SETIAWAN (๑ orcid.org/0000-0002-6090-906X) SwaraOwa, Kalitirto, Berbah, Sleman, Yogyakarta, Indonesia. E-mail ec.cahyaningrum@gmail.com

This is an Open Access article, distributed under the Creative Commons Attribution license CC BY NC ND 4.0. 